\title{
Compositional attributes and fatty acid profile of lamb meat from Iberian local breeds
}

\author{
Vasco A.P. Cadavez ${ }^{\mathrm{a}, *}$, Teodora Popova ${ }^{\mathrm{b}}$, Roberto Bermúdez ${ }^{\mathrm{c}}$, Koldo Osoro ${ }^{\mathrm{d}}$, Laura Purriños ${ }^{\mathrm{c}}$, \\ Raúl Bodas $^{\mathrm{e}}$, José M. Lorenzo ${ }^{\text {c,f }}$, Ursula Gonzales-Barron ${ }^{\mathrm{a}}$ \\ ${ }^{a}$ Centro de Investigação de Montanha (CIMO), Instituto Politécnico de Bragança, 5300-253 Bragança, Portugal \\ ${ }^{\mathrm{b}}$ Agricultural Academy, Institute of Animal Science, 2232 Kostinbrod, Bulgaria \\ ${ }^{\mathrm{c}}$ Centro Tecnológico de la Carne de Galicia, Rúa Galicia No 4, Parque Tecnológico de Galicia, San Cibrao das Viñas, 32900, Ourense, Spain \\ d Servicio Regional de Investigación y Desarrollo Agroalimentario (SERIDA), Ctra. de Oviedo s/n., 33300 Villaviciosa, Asturias, Spain \\ e Instituto Tecnológico Agrario de Castilla y León, Leon, Spain \\ f Área de Tecnología de los Alimentos, Facultad de Ciencias de Ourense, Universidad de Vigo, 32004 Ourense, Spain
}

\section{A R T I C L E I N F O}

\section{Keywords:}

Sheep

Autochthonous breeds

Nutritional quality

Cholesterol

$\alpha$-Tocopherol

Retinol

\begin{abstract}
A B S T R A C T
This study aimed to compare lamb meat composition from five Iberian breeds raised in their typical rearing systems and to reveal trends in compositional meat attributes due to breed or production system. The meat quality of 153 animals was analysed. The combined effect of breed $\times$ production system produced significant differences in lamb meat quality. Meat from the extensively-reared Bordaleira-de-Entre-Douro-e-Minho (BEDM) and Gallega breeds had elevated amounts of n-3 PUFAs, tocopherol content and favourable n-6/n-3 ratio. Meat from lambs grown under extensive and semi-extensive systems presented higher content of conjugated linoleic acid than the two breeds reared intensively. The meat of commercial breed (INRA401) was characterised by higher content of protein and MUFAs and lower atherogenic potential than the breeds reared in extensive and semi-extensive systems. Principal component analysis demonstrated that meat from extensively raised lambs was associated to higher SFA, CLA, $\alpha$-tocopherol, n-3, atherogenic index and cholesterol content, but lower intramuscular fat and retinol content, MUFA and n-6/n-3.
\end{abstract}

\section{Introduction}

Sheep farming is an activity of economic importance in the European Union (EU). There are $\sim 83$ million sheep, often raised in economically vulnerable areas such as mountain regions, with nearly two thirds of the animals distributed in the UK (26.3\%), Spain (18.5\%), Romania (11.9 $\%$ ) and Greece (9.9\%) (Eurostat, 2019). Only in the Iberian peninsula, there is considerable variation in the sheep production systems, which are strongly influenced by land type. Sheep production is more likely to be found in low farming areas, where sheep graze natural vegetation and agricultural waste (Cruz et al., 2019); whereas they are also raised in intensively managed lands (Anonymous, 2000). These animal production systems have contributed to the maintenance of the ecological balance of natural pastures, and the environmental and socio-cultural richness of the Iberian peninsula's landscapes.

Many of the Iberian sheep breeds are native: there are 16 indigenous breed sheep in Portugal and 42 in Spain. From these, at least 32 are at risk of becoming extinct (De-Arriba and Sánchez-Andrés, 2014). However, the indigenous sheep breeds, in addition to contributing to the diversity of production systems, are important genetic resources that must be preserved because of their local adaptation, disease resistance, high fertility and unique product qualities (Mendelsohn, 2003). Some of these breeds, classified as threatened, have small body size and good adaptation to adverse environments (climate and orography), which makes them particularly well suited to the use and enhancement of natural pastures (Cruz et al., 2019).

Increasing added value of sheep meat and its products through sustainable quality and development of named origin and ecological products are mechanisms to support the sheep farming sector, increase the profitability of sheep farmers, and protect local and endangered breeds (De-Arriba and Sánchez-Andrés, 2014). On the other hand, the current consumer is sensitive to management practices capable of preserving local breeds and improving the welfare of animals; and they are available to pay a higher price for certified products with quality seals.

\footnotetext{
* Corresponding author.

E-mail address: vcadavez@ipb.pt (V.A.P. Cadavez).
} 
Meat quality is a multidimensional concept encompassing organoleptic, nutritional and microbiological characteristics, which are regulated by factors that are intrinsic and extrinsic to the animal. Fatty acid composition alone has a strong impact on the nutritive value and the organoleptic characteristics of meat (Díaz et al., 2005). The flavour profile, an important attribute of meat, is regulated by variations in the absolute concentration and the relative proportions of different fatty acids (Fisher et al., 2000). Multiple studies have confirmed that fatty acid composition can be influenced by production system, animal breed and sex, slaughter age and weight, and level of fatness (Atti and Mahouachi, 2009; Boughalmi and Araba, 2016; Carrasco et al., 2009; Ekiz et al., 2013; Nürnberg et al., 1998).

Therefore, the objective of this study was twofold: (i) to evaluate the fatty acid profile and chemical composition of lamb meat originating from 6 farms housing 5 Iberian breeds typically raised in extensive, semi-extensive or intensive regime; and (ii) to elucidate interrelationships among the compositional attributes of lamb meat, and their trends due to breed or production system.

\section{Methodology}

\subsection{Lamb rearing and feeding}

Four autochthonous sheep breeds exploited for meat production, in their typical production systems, were utilised in the present study: Churra-Galega-Bragançana (CGB - extensive) and Bordaleira-de-EntreDouro-e-Minho (BEDM - extensive), from the Mediterranean and the Atlantic bioregion of Portugal, respectively; Castellana (intensive and semi-extensive) from the Mediterranean bioregion of Spain; and Gallega (extensive) from the Atlantic bioregion of Spain. For comparison, a commercial sheep breed (INRA401, intensively raised) was included in this study. A total of 153 lambs, all born as single, were employed in this study, from the following breeds and production systems: BEDM extensive $(n=28)$, Castellana intensive $(n=30)$, Castellana semiextensive $(n=15)$, CGB semi-extensive $(n=30)$, Gallega extensive $(\mathrm{n}=36)$ and INRA401 intensive $(\mathrm{n}=14)$.

\subsubsection{Portugal}

In the Mediterranean region, located in Bragança, CGB lambs were raised on the holding of the School of Agriculture of the Polytechnic Institute of Bragança. In the Atlantic bioregion, located in Ponte de Lima, BEDM lambs were raised on the holding of the Ponte de Lima Agrarian School. The production system used for BEDM lambs was the extensive one, while for CGB lambs the semi-extensive system, whose feeding was based on grazing on natural pastures. The hours of grazing varied according to hours of light, heat and herd size. In winter, the flocks would be released in the morning to graze all day until dark. In the summer, the herds would leave at dawn and graze until midmorning, then they would be put in a stable under shade, and would come out when the heat had subsided. Once on the premises, all lambs had access to meadow hay and water ad libitum, but the semi-extensively raised lambs were also supplemented with protein and mineral-rich concentrates. The lambs had access to mother's milk during the growth trial (not weaned), and were reared in the fall of 2018 and spring 2019. For this investigation, 15 BEDM (10 males and 5 females) and 15 CGB (9 males and 6 females) lambs were reared in 2018, and 13 BEDM ( 8 males and 5 females) and 15 CGB (10 males and 5 females) lambs were reared in 2019.

\subsubsection{Spain}

In the Mediterranean regions of Salamanca (for INRA-401 breed) and Zamora (for Castellana breed), lambs were raised under an intensive system on commercial farms. Lambs were weaned when they were 4-6 weeks old and housed with straw bedding and free access to commercial concentrate, cereal straw and fresh water. In the Mediterranean region, located in Valladolid, Castellana breed lambs were raised under a semi- extensive system. Animals were weaned at 4-6 weeks old and housed together with straw bedding, allowed to graze outdoors (pastures were predominately oak and pine forests, cereal stubbles and vineyards) during the mornings; animals were kept indoors during the afternoon and night, with free access to commercial concentrate, cereal straw and fresh water. Fourteen INRA-401 and 15 Castellana (from Zamora) lambs were reared in the spring of 2018, while 30 Castellana lambs (15 from Zamora and 15 from Valladolid) were reared in the spring of 2019. All lambs were male.

In Asturias (northern Spain, Atlantic bioregion), lambs were reared with their dams at the SERIDA experimental farm located in Grado. Lambs of Gallega breed were born during winter, grown suckling their mothers on pasture, and weaned in late spring-early summer before their slaughter at an age of $\sim 4$ months. In 2018, thirty-six lambs (11 males and 25 females) were raised in an extensive system on 12 experimental paddocks (half with apple trees) sown with perennial ryegrass (Lolium perenne) and white clover (Trifolium repens) and organically managed (without synthetic fertilisers), where grazing season started in early April.

Production, transport and slaughter of lambs was carried out according to the normal commercial conditions of Portugal and Spain; and since, in addition, no invasive procedures were carried out, approval from the animal ethics committee was not required in this investigation.

\subsection{Preparation of lamb meat samples}

All lambs were 4-4.5 months old when slaughtered. Lambs were slaughtered in batches ranging from 5 to 12 animals in local abattoirs of Portugal and Spain.Lambs were slaughtered after an overnight lairage period, where they had free access to water but not to feed. In the abattoirs, lambs were electrically stunned, dressed, washed and chilled at $4{ }^{\circ} \mathrm{C}$. Twenty-four hours after slaughter, carcasses were split and the Longissimus thoracis et lumborum muscles removed from the 6th to the 13th vertebra under aseptic conditions. The right side was divided into two parts for subsequent laboratorial analysis. They were vacuum packed in transparent gas-tight polyamide and polyethylene vacuum bags (Orved $\AA$, Spain, with permeability of $84 \pm 4.20 \mathrm{cc} / \mathrm{m}^{2} / 24 \mathrm{~h} / \mathrm{atm}$ for $\mathrm{O}_{2}, 361 \pm 18.05 \mathrm{cc} / \mathrm{m}^{2} / 24 \mathrm{~h} / \mathrm{atm}$ for $\mathrm{CO}_{2}, 22 \pm 1.10 \mathrm{cc} / \mathrm{m}^{2} / 24 \mathrm{~h} /$ atm for $\mathrm{N}_{2}$ and $9.0 \pm 0.45 \mathrm{cc} / \mathrm{m}^{2} / 24 \mathrm{~h} / \mathrm{atm}$ for $\mathrm{H}_{2} \mathrm{O}$ and density of $\pm 100 \mu \mathrm{m}$ ), and stored at $4 \pm 0.5^{\circ} \mathrm{C}$. Within $24 \mathrm{~h}$, the meat samples were subjected to the following determinations: proximate composition, fatty acid composition and concentrations of cholesterol, retinol and $\alpha$-tocopherol.

\subsection{Chemical composition analyses}

\subsubsection{Proximate composition}

Moisture, intramuscular fat, protein and ashes contents were determined according to ISO 1442 (1997); AOCS (2005); ISO 937 (1978) and ISO 936 (1998), respectively. Determinations were made in triplicate per meat sample.

\subsubsection{Fatty acids analysis}

Intramuscular lipids were extracted following the method described by Bligh and Dyer (1959) with the modifications proposed by Barros et al. (2020). The procedure described by Barros et al. (2020) was used for fatty acids determination. Briefly, $20 \mathrm{mg}$ of extracted fat were transesterified with sodium methoxide $(0.5 \mathrm{~N})$ and $\mathrm{H}_{2} \mathrm{SO}_{4}$ solution $(10 \%$ of $\mathrm{H}_{2} \mathrm{SO}_{4}$ in methanol). Then, the fatty acid methyl esters (FAMEs) were extracted with hexane and transferred to a gas chromatography vial. Separation and quantification of FAMEs were carried out using a gas chromatograph (GC-Agilent 7890B, Agilent Technologies, Santa Clara, CA, USA) equipped with a flame ionization detector (FID) and PAL RTC-120 auto sampler. One microliter of sample was injected in split mode (1:50). For the separation of FAMEs, a DB-23 fused silica capillary column ( $60 \mathrm{~m}, 0.25 \mathrm{~mm}$ i.d., $0.25 \mu \mathrm{m}$ film thickness; Agilent 
Technologies) was used. Chromatographic conditions were as follows: initial oven temperature of $50^{\circ} \mathrm{C}$ (held for $1 \mathrm{~min}$ ), first ramp at $25^{\circ} \mathrm{C} / \mathrm{min}$ to $175^{\circ} \mathrm{C}$, second ramp at $4{ }^{\circ} \mathrm{C} / \mathrm{min}$ to $230^{\circ} \mathrm{C}$ (held for $5 \mathrm{~min}$ ) and third ramp at $4{ }^{\circ} \mathrm{C} / \mathrm{min}$ to a final temperature of $240^{\circ} \mathrm{C}$ (held for $2.75 \mathrm{~min}$ ). Helium was used as a carrier gas at a constant flow-rate of $1.2 \mathrm{~mL} / \mathrm{min}$. The FID detector was maintained at $280^{\circ} \mathrm{C}$, while the operational flows were set as $40 \mathrm{~mL} / \mathrm{min}$ of $\mathrm{H}_{2}, 450 \mathrm{~mL} / \mathrm{min}$ of air and $30 \mathrm{~mL} / \mathrm{min}$ of makeup flow. Individual FAMEs were identified by comparing their retention times with those of authenticated standards and the results were expressed as percentage of the total FAMEs.

The total contents of saturated fatty acids (SFAs), monounsaturated fatty acids (MUFAs), polyunsaturated fatty acids (PUFAs), PUFA n- 6 and PUFA n-3 were calculated. The PUFA $n-6 / n-3$ ratios were also calculated. The atherogenic (AI) and thrombogenic (TI) indices, as proposed by Ulbricht and Southgate (1991), were calculated according to the following equations:

$$
\begin{aligned}
& \mathrm{AI}=(\mathrm{C} 12: 0+4 \times \mathrm{C} 14: 0+\mathrm{C} 16: 0) /[\mathrm{MUFA}+\Sigma(\mathrm{n}-6)+\Sigma(\mathrm{n}-3)] \\
& \mathrm{TI}=(\mathrm{C} 14: 0+\mathrm{C} 16: 0+\mathrm{C} 18: 0) /[0.5 \times \operatorname{MUFA}+0.5 \times(\mathrm{n}-6)+3 \times(\mathrm{n}-3)+(\mathrm{n}-3) /(\mathrm{n}- \\
& 6)]
\end{aligned}
$$

\subsubsection{Cholesterol analysis}

Total cholesterol was analysed (saponification, separation and quantification) following the procedure described by Domínguez et al. (2018). Two grams of homogenised meat sample were placed in a screw teflon-lined cap tube and $0.25 \mathrm{~g}$ of L-ascorbic acid and $5 \mathrm{~mL}$ of saponification solution [ $11 \%$ potassium hydroxide in ethanol solution (55\%)] were added. The saponification step was carried out in a shaking water bath at $85^{\circ} \mathrm{C}$ for $45 \mathrm{~min}$. After cooling, cholesterol was extracted with $1.5 \mathrm{~mL}$ of hexane. Cholesterol was separated and quantified using normal phase-HPLC technique, according the chromatographic conditions reported by Domínguez et al. (2018). The HPLC systems used was an Alliance 2695 model (Waters, Milford, USA) equipped with a 996 Photodiode Array Detector (Waters Milford, USA). The cholesterol analysis were performed using a normal-phase silica column (SunFireTM Prep Silica, $4.6 \mathrm{~mm}$ ID $\times 250 \mathrm{~mm}, 5 \mu \mathrm{m}$ particle size, Waters, Milford, MA, USA). The mobile phase ( $2 \% \mathrm{v} / \mathrm{v} 2$-propanol in n-hexane) flow rate was $1 \mathrm{ml} / \mathrm{min}$, the run last for $15 \mathrm{~min}$ and the temperature of the column oven was adjusted at $30^{\circ} \mathrm{C}$. The detection of cholesterol was carry out using Photodiode Array detector at $208 \mathrm{~nm}$. Results were expressed as $\mathrm{mg}$ of cholesterol/100 $\mathrm{g}$ of meat.

\subsubsection{Retinol and $\alpha$-tocopherol analyses}

The procedure described by Roselló-Soto et al. (2019) was used for the retinol and $\alpha$-tocopherol determination. One hundred milligrams of extracted fat (Barros et al., 2020) were dissolved in $1.8 \mathrm{~mL}$ of $\mathrm{n}$-hexane and then filtered through a $0.45 \mu \mathrm{m}$ hydrophobic membrane into an amber screw-cap vial with teflon septum. The HPLC systems used in the determination was an Alliance 2695 model (Waters, Milford, USA) equipped with a 2475 Multi- $\lambda$ Fluorescence Detector (Waters Milford, USA). The same chromatographic conditions reported for cholesterol analysis (column, phase mobile, flow rate and column temperature) were employed in the determination of retinol and $\alpha$-tocopherol. Regarding detection, both compounds were detected using the Fluorescence detector (retinol: $\lambda$-excitation $344 \mathrm{~nm} / \lambda$-emission $472 \mathrm{~nm}$; $\alpha$-tocopherol: $\lambda$-excitation $290 \mathrm{~nm} / \lambda$-emission $330 \mathrm{~nm}$ ). The results of both compounds were expressed as $\mu \mathrm{g} / \mathrm{g}$ of fat.

\subsection{Statistical analysis}

Each chemical or nutritional attribute of meat was subjected to oneway analysis of variance to assess the effect of breed $\times$ production system. When the effect was significant ( $\alpha=0.05$ ), the least square means of the quality attribute for the breed $\times$ production systems were compared by the Tukey's Honest Significant Difference test $(\alpha=0.05)$. In addition, a principal component analysis (PCA) on the variables intramuscular fat content, CLA, fatty acid indexes, retinol, $\alpha$-tocopherol and cholesterol concentrations were conducted to evaluate the relative differences of the meat samples in these chemical components among breeds and production systems. Statistical analyses were conducted using the packages "car" and "Ismeans" for the linear models, and "factoextra" for the principal component analysis, implemented in the $\mathrm{R}$ software version 3.3.3 (R Core Team, 2019).

\section{Results}

\subsection{Effect of breed $\times$ production system on the chemical composition of lamb meat}

The major chemical components of the meat, its cholesterol and vitamin content differed substantially among the breed $\times$ production systems (Table 1). Of all breeds, the lambs of BEDM breed showed the lowest intamuscular fat content, while the highest was recorded in the intensively reared Castellana animals $(0.891 \%$ and $2.358 \%$ respectively). The opposite was observed in regard to the moisture content, being highest in the BEDM lambs and tending to be lower in the Castellana animals in intensive conditions, when compared to the semi extensively reared CGB and exyensively reared Callega. When comparing the examined breeds it could be noticed that in regard to protein content, BEDM and Castellana/I differed significantly, showing minimum and maximum values of this trait $(20.06 \%$ vs. $21.52 \%)$. Furthrmore, BEDM lamb had lower potein content when compred to the extensive Callega and INRA, whereas the intensively reared Castellana showed higher values of this trait in comparison to semiextensive CGB and Castellana.

The lowest ash content was measured in the meat of Castellana lambs, reared both under intensive (1.194\%) and semi-extensive (1.164 $\%)$ production systems, followed by INRA401 (1.229 \%) and CGB (1.242 $\%)$. In comparison to these breeds, the meat of Gallega lambs presented the highest ash content $(1.346 \%)$. In this study, the cholesterol content of meat was so variable that could not be clearly discriminated between the breed $\times$ production systems. However, the highest cholesterol content was measured in the meat of Gallega lambs $(66.876 \mathrm{mg} / 100 \mathrm{~g}$ meat), and the lowest in Castellana, reared intensively $(40.971 \mathrm{mg} /$ $100 \mathrm{~g}$ meat). The two breeds reared under semi-extensive systems also showed relatively lower cholesterol levels $(43.500-44.970 \mathrm{mg} / 100 \mathrm{~g}$ meat). The contents of $\alpha$-tocopherol and retinol differed significantly among the production systems: extensively raised lambs produced meat of higher $\alpha$-tocopherol content (95.972-107.219 $\mu \mathrm{g} / \mathrm{g}$ fat) than the semiextensively raised (30.573-33.486 $\mu \mathrm{g} / \mathrm{g}$ fat), which in turn tended to be higher than the meat produced by intensively raised lambs (16.239-22.564 $\mu \mathrm{g} / \mathrm{g}$ fat). By contrast, meat from intensively raised animals rendered meat of higher retinol content $(2.871-3.472 \mu \mathrm{g} / \mathrm{g}$ fat $)$ than that of extensive or semi-extensive productions $(1.407-1.471 \mu \mathrm{g} / \mathrm{g}$ fat).

\subsection{Effect of breed $\times$ production system on the fatty acid composition and lipid nutritional indices of lamb meat}

The lamb breed production system affected significantly the fatty acid profile (Table 2) and the lipid indices of meat (Table 3). In this study, a total of 40 fatty acids were identified. The total amount of the saturated fatty acids varied within the range of $39.413 \%-45.856 \%$. The major saturated fatty acids are C16:0 and C18:0. BEDM showed the lowest percentage of C16:0 (19.890\%), while the semi-extensively reared Castellana had the highest percentage $(24.674 \%)$. The proportion of C18:0 was the highest in both BEDM (14.860\%) and Gallega $(15.367 \%)$. The third important saturated fatty acid showing considerable amounts in the meat is $\mathrm{C} 14: 0$. The lowest proportions of this fatty acid were observed in the two intensively reared breeds, Castellana 
Table 1

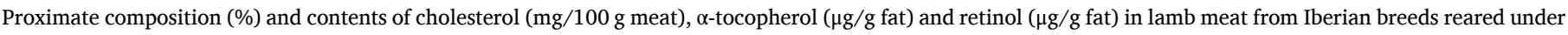
extensive (E), semi-extensive (SE) or intensive (I) production systems.

\begin{tabular}{|c|c|c|c|c|c|c|c|c|}
\hline Attribute $^{1}$ & $\mathrm{BEDM}^{2} / \mathrm{E}$ & Gallega/E & $\mathrm{CGB}^{3} / \mathrm{SE}$ & Castellana/SE & Castellana/ I & INRA401/I & $\mathrm{SEM}^{4}$ & $\mathrm{Sig}^{5}$ \\
\hline Intramuscular fat & $0.891^{\mathrm{c}}$ & $1.756^{\mathrm{b}}$ & $1.675^{\mathrm{b}}$ & $1.799^{\mathrm{b}}$ & $2.358^{\mathrm{a}}$ & $1.785^{\mathrm{b}}$ & 0.760 & $* * *$ \\
\hline Protein & $20.06^{\mathrm{c}}$ & $20.97^{\mathrm{ab}}$ & $20.62^{b c}$ & $20.45^{\mathrm{bc}}$ & $21.52^{\mathrm{a}}$ & $21.17^{\mathrm{ab}}$ & 0.892 & $* * *$ \\
\hline Moisture & $77.03^{\mathrm{a}}$ & $75.65^{\mathrm{b}}$ & $75.90^{\mathrm{b}}$ & $75.79^{b c}$ & $74.81^{\mathrm{c}}$ & $75.18^{\mathrm{bc}}$ & 1.106 & $* * *$ \\
\hline Ash & $1.289^{\mathrm{ab}}$ & $1.346^{\mathrm{a}}$ & $1.242^{\mathrm{bc}}$ & $1.164^{\mathrm{c}}$ & $1.194^{\mathrm{c}}$ & $1.229^{\mathrm{bc}}$ & 0.092 & $* * *$ \\
\hline Cholesterol & $56.37^{\mathrm{ab}}$ & $66.88^{\mathrm{a}}$ & $44.97^{\mathrm{bc}}$ & $43.50^{\mathrm{bc}}$ & $40.97^{c}$ & $55.28^{\mathrm{ab}}$ & 19.97 & $* * *$ \\
\hline$\alpha$-tocopherol & $107.2^{\mathrm{a}}$ & $95.97^{\mathrm{a}}$ & $33.49^{\mathrm{b}}$ & $30.57^{\mathrm{b}}$ & $16.24^{\mathrm{c}}$ & $22.56^{\mathrm{bc}}$ & 26.36 & $* * *$ \\
\hline Retinol & $1.471^{\mathrm{b}}$ & $1.395^{\mathrm{b}}$ & $1.470^{\mathrm{b}}$ & $1.407^{\mathrm{b}}$ & $2.871^{\mathrm{a}}$ & $3.472^{\mathrm{a}}$ & 1.006 & $* * *$ \\
\hline
\end{tabular}

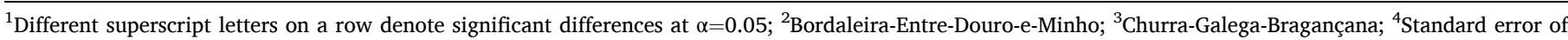
means; ${ }^{5}$ Level of significance $* * * \mathrm{p}<.0001$.

Table 2

Fatty acid (FA) composition (\%) of lamb meat from Iberian breeds reared under extensive (E), semi-extensive (SE) or intensive (I) production systems.

\begin{tabular}{|c|c|c|c|c|c|c|c|c|}
\hline $\mathrm{FA}^{1}$ & $\mathrm{BEDM}^{2} / \mathrm{E}$ & Gallega/E & $\mathrm{CGB}^{3} / \mathrm{SE}$ & Castellana/SE & Castellana/ I & INRA401/I & SEM $^{4}$ & $\mathrm{Sig}^{5}$ \\
\hline C6:0 & $0.273^{\mathrm{a}}$ & $0.031^{\mathrm{b}}$ & $<0.001^{\mathrm{b}}$ & $<0.001^{\mathrm{b}}$ & $0.001^{\mathrm{b}}$ & $<0.001^{\mathrm{b}}$ & 0.118 & $* * *$ \\
\hline C8:0 & $<0.001^{\mathrm{c}}$ & $0.004^{\mathrm{b}}$ & $0.004^{\mathrm{b}}$ & $0.001^{\mathrm{bc}}$ & $0.008^{\mathrm{a}}$ & $0.009^{\mathrm{a}}$ & 0.003 & $* * *$ \\
\hline C10:0 & $0.148^{\mathrm{bc}}$ & $0.159^{\mathrm{bc}}$ & $0.173^{\mathrm{b}}$ & $0.239^{\mathrm{a}}$ & $0.127^{\mathrm{c}}$ & $0.140^{\mathrm{bc}}$ & 0.046 & $* * *$ \\
\hline C11:0 & $0.004^{\mathrm{ab}}$ & $0.007^{\mathrm{a}}$ & $0.002^{\mathrm{b}}$ & $0.002^{\mathrm{b}}$ & $<0.001^{\mathrm{b}}$ & $<0.001^{\mathrm{b}}$ & 0.004 & $* * *$ \\
\hline $\mathrm{C} 12: 0$ & $0.375^{\mathrm{b}}$ & $0.344^{\mathrm{bc}}$ & $0.264^{\mathrm{c}}$ & $0.537^{\mathrm{a}}$ & $0.067^{\mathrm{d}}$ & $0.145^{\mathrm{d}}$ & 0.121 & $* * *$ \\
\hline C13:0 & $0.018^{\mathrm{b}}$ & $0.034^{\mathrm{a}}$ & $0.018^{\mathrm{b}}$ & $0.025^{\mathrm{ab}}$ & $0.008^{\mathrm{c}}$ & $0.013^{b c}$ & 0.012 & $* * *$ \\
\hline C14:0 & $3.450^{c}$ & $4.191^{\mathrm{b}}$ & $3.694^{b c}$ & $5.459^{\mathrm{a}}$ & $1.821^{\mathrm{d}}$ & $2.350^{\mathrm{d}}$ & 0.930 & $* * *$ \\
\hline C15:0 & $0.543^{\mathrm{b}}$ & $0.614^{\mathrm{b}}$ & $0.338^{\mathrm{c}}$ & $0.572^{\mathrm{b}}$ & $0.537^{\mathrm{b}}$ & $1.218^{\mathrm{a}}$ & 0.165 & $* * *$ \\
\hline $\mathrm{C} 16: 0$ & $19.89^{c}$ & $22.13^{\mathrm{b}}$ & $22.96^{\mathrm{b}}$ & $24.67^{\mathrm{a}}$ & $22.45^{\mathrm{b}}$ & $23.45^{\mathrm{ab}}$ & 1.850 & $* * *$ \\
\hline C17:0 & $1.916^{\mathrm{a}}$ & $1.135^{\mathrm{c}}$ & $0.828^{\mathrm{d}}$ & $1.100^{\mathrm{cd}}$ & $1.570^{\mathrm{b}}$ & $1.591^{\mathrm{ab}}$ & 0.396 & $* * *$ \\
\hline C18:0 & $14.86^{\mathrm{a}}$ & $15.37^{\mathrm{a}}$ & $12.32^{\mathrm{b}}$ & $13.05^{\mathrm{b}}$ & $12.56^{\mathrm{b}}$ & $11.21^{\mathrm{b}}$ & 1.837 & $* * *$ \\
\hline $\mathrm{C} 20: 0$ & $0.139^{\mathrm{a}}$ & $0.120^{\mathrm{ab}}$ & $0.093^{\mathrm{bc}}$ & $0.117^{\mathrm{ab}}$ & $0.071^{\mathrm{c}}$ & $0.067^{c}$ & 0.044 & $* * *$ \\
\hline C21:0 & $0.029^{\mathrm{ab}}$ & $0.028^{\mathrm{ab}}$ & $0.021^{\mathrm{ab}}$ & $<0.001^{\mathrm{b}}$ & $0.049^{\mathrm{b}}$ & $<0.001^{\mathrm{b}}$ & 0.045 & $* *$ \\
\hline C22:0 & $0.681^{\mathrm{a}}$ & $0.538^{\mathrm{a}}$ & $0.205^{\mathrm{b}}$ & $0.022^{\mathrm{b}}$ & $0.109^{b}$ & $0.275^{\mathrm{b}}$ & 0.240 & $* * *$ \\
\hline C23:0 & $<0.001^{\mathrm{b}}$ & $<0.001^{\mathrm{b}}$ & $<0.001^{\mathrm{b}}$ & $0.056^{\mathrm{a}}$ & $0.028^{\mathrm{a}}$ & $<0.001^{\mathrm{b}}$ & 0.032 & $* * *$ \\
\hline $\mathrm{C} 24: 0$ & $0.031^{\mathrm{a}}$ & $0.030^{\mathrm{a}}$ & $0.001^{\mathrm{b}}$ & $<0.001^{\mathrm{b}}$ & $0.008^{\mathrm{b}}$ & $0.034^{\mathrm{a}}$ & 0.018 & $* * *$ \\
\hline SFA & $42.36^{\mathrm{b}}$ & $44.73^{\mathrm{ab}}$ & $40.91^{\mathrm{bc}}$ & $45.86^{\mathrm{a}}$ & $39.41^{c}$ & $40.50^{\mathrm{bc}}$ & 3.065 & $* * *$ \\
\hline C14:1n-5 & $0.116^{\mathrm{d}}$ & $0.157^{\mathrm{cd}}$ & $0.183^{b c}$ & $0.242^{\mathrm{b}}$ & $0.143^{\mathrm{cd}}$ & $0.463^{\mathrm{a}}$ & 0.076 & $* * *$ \\
\hline C15:1n-5 & $0.537^{\mathrm{bc}}$ & $0.116^{\mathrm{c}}$ & $0.265^{b c}$ & $2.200^{\mathrm{a}}$ & $0.601^{\mathrm{b}}$ & $0.000^{c}$ & 0.64 & $* * *$ \\
\hline C16:1n-7 & $1.229^{c}$ & $1.488^{\mathrm{b}}$ & $1.884^{\mathrm{a}}$ & $2.002^{\mathrm{a}}$ & $1.796^{\mathrm{a}}$ & $1.973^{\mathrm{a}}$ & 0.311 & $* * *$ \\
\hline C17:1n-7 & $0.321^{\mathrm{c}}$ & $0.636^{\mathrm{b}}$ & $0.282^{\mathrm{c}}$ & $0.717^{\mathrm{b}}$ & $1.044^{\mathrm{a}}$ & $1.232^{\mathrm{a}}$ & 0.229 & $* * *$ \\
\hline C18:1n-9tr & $0.386^{c}$ & $1.070^{\mathrm{ab}}$ & $0.863^{\mathrm{b}}$ & $0.357^{c}$ & $1.279^{\mathrm{a}}$ & $1.399^{\mathrm{a}}$ & 0.428 & $* * *$ \\
\hline C18:1n-7tr & $1.579^{\mathrm{cd}}$ & $2.508^{\mathrm{b}}$ & $2.079^{\mathrm{bc}}$ & $0.760^{\mathrm{d}}$ & $3.413^{\mathrm{a}}$ & $1.869^{\mathrm{bc}}$ & 0.891 & $* * *$ \\
\hline C18:1n-9cis & $29.06^{c}$ & $34.62^{\mathrm{b}}$ & $36.99^{\mathrm{a}}$ & $33.87^{\mathrm{b}}$ & $38.38^{\mathrm{a}}$ & $37.85^{\mathrm{a}}$ & 2.850 & $* * *$ \\
\hline C18:1n-7cis & $0.624^{c}$ & $0.804^{\mathrm{bc}}$ & $0.903^{\mathrm{b}}$ & $1.029^{\mathrm{b}}$ & $1.917^{\mathrm{a}}$ & $1.958^{\mathrm{a}}$ & 0.319 & $* * *$ \\
\hline C20:1n-9 & $0.146^{c}$ & $0.088^{d}$ & $0.106^{\text {cd }}$ & $0.123^{\mathrm{bc}}$ & $0.171^{\mathrm{a}}$ & $0.113^{\mathrm{cd}}$ & 0.031 & $* * *$ \\
\hline C22:1n-9 & $0.069^{\mathrm{b}}$ & $0.023^{c}$ & $0.009^{c}$ & $0.025^{c}$ & $0.065^{\mathrm{b}}$ & $0.147^{\mathrm{a}}$ & 0.035 & $* * *$ \\
\hline C24:1n-9 & $<0.001^{\mathrm{b}}$ & $0.007^{\mathrm{a}}$ & $<0.001^{\mathrm{b}}$ & $<0.001^{\mathrm{b}}$ & $<0.001^{\mathrm{b}}$ & $<0.001^{\mathrm{b}}$ & 0.004 & $* * *$ \\
\hline MUFA & $34.07^{\mathrm{d}}$ & $41.51^{\mathrm{c}}$ & $43.57^{b}$ & $41.32^{\mathrm{bc}}$ & $48.81^{\mathrm{a}}$ & $47.00^{\mathrm{ab}}$ & 5.500 & $* * *$ \\
\hline $\mathrm{C} 18: 2 \mathrm{n}-6 \mathrm{tr}$ & $0.353^{\mathrm{a}}$ & $0.082^{\mathrm{b}}$ & $0.147^{\mathrm{b}}$ & $0.179^{\mathrm{b}}$ & $0.094^{\mathrm{b}}$ & $0.145^{\mathrm{b}}$ & 0.128 & $* * *$ \\
\hline $\mathrm{C} 18: 2 \mathrm{n}-6$ & $9.480^{\mathrm{a}}$ & $4.760^{\mathrm{d}}$ & $8.474^{\mathrm{ab}}$ & $6.358^{\mathrm{cd}}$ & $7.500^{\mathrm{bc}}$ & $7.707^{\mathrm{abc}}$ & 2.112 & $* * *$ \\
\hline C18:3n-6 & $0.083^{c}$ & $0.050^{\mathrm{d}}$ & $0.095^{b c}$ & $0.080^{c}$ & $0.107^{\mathrm{ab}}$ & $0.116^{\mathrm{a}}$ & 0.021 & $* * *$ \\
\hline C18:3n-3 & $2.396^{\mathrm{a}}$ & $1.596^{\mathrm{b}}$ & $0.596^{c}$ & $0.673^{c}$ & $0.308^{d}$ & $0.302^{\mathrm{d}}$ & 0.268 & $* * *$ \\
\hline CLA & $0.824^{\mathrm{b}}$ & $1.804^{\mathrm{a}}$ & $0.842^{\mathrm{b}}$ & $0.427^{c}$ & $0.197^{\mathrm{cd}}$ & $0.185^{\mathrm{d}}$ & 0.240 & $* * *$ \\
\hline$C 20: 2 n-6$ & $0.065^{\mathrm{cd}}$ & $0.032^{\mathrm{d}}$ & $0.069^{c}$ & $0.405^{\mathrm{a}}$ & $0.141^{\mathrm{b}}$ & $0.079^{c}$ & 0.048 & $* * *$ \\
\hline C20:3n-6 & $0.412^{\mathrm{a}}$ & $0.210^{\mathrm{b}}$ & $0.270^{\mathrm{b}}$ & $0.235^{\mathrm{b}}$ & $0.211^{\mathrm{b}}$ & $0.219^{\mathrm{b}}$ & 0.119 & $* * *$ \\
\hline C20:3n-3 & $0.173^{\mathrm{a}}$ & $0.131^{\mathrm{a}}$ & $0.069^{b}$ & $0.045^{\mathrm{b}}$ & $0.035^{b c}$ & $0.000^{c}$ & 0.073 & $* * *$ \\
\hline C20:4n-6 & $5.197^{\mathrm{a}}$ & $2.347^{c}$ & $3.578^{\mathrm{b}}$ & $3.389^{\mathrm{bc}}$ & $2.545^{\mathrm{bc}}$ & $2.740^{\mathrm{bc}}$ & 1.577 & $* * *$ \\
\hline$C 22: 2 n-6$ & $0.035^{\mathrm{a}}$ & $0.030^{\mathrm{a}}$ & $0.004^{\mathrm{b}}$ & $<0.001^{\mathrm{b}}$ & $0.002^{\mathrm{b}}$ & $<0.001^{\mathrm{b}}$ & 0.019 & $* * *$ \\
\hline C20:5n-3 & $1.734^{\mathrm{a}}$ & $1.156^{\mathrm{b}}$ & $0.263^{c}$ & $0.201^{\mathrm{c}}$ & $0.089^{c}$ & $0.112^{\mathrm{c}}$ & 0.351 & $* * *$ \\
\hline C22:5n-6 & $0.190^{\mathrm{bc}}$ & $0.108^{\mathrm{cd}}$ & $0.212^{\mathrm{b}}$ & $0.000^{\mathrm{d}}$ & $0.205^{b c}$ & $0.390^{\mathrm{a}}$ & 0.139 & $* * *$ \\
\hline C22:5n-3 & $1.961^{\mathrm{a}}$ & $1.111^{\mathrm{b}}$ & $0.654^{\mathrm{c}}$ & $0.594^{\mathrm{cd}}$ & $0.286^{d}$ & $0.374^{\mathrm{cd}}$ & 0.414 & $* * *$ \\
\hline$C 22: 6 n-3$ & $0.670^{\mathrm{a}}$ & $0.340^{\mathrm{b}}$ & $0.245^{c}$ & $0.234^{\mathrm{bc}}$ & $0.061^{\mathrm{d}}$ & $0.124^{\mathrm{cd}}$ & 0.131 & $* * *$ \\
\hline PUFA & $23.57^{\mathrm{a}}$ & $13.76^{\mathrm{b}}$ & $15.52^{\mathrm{a}}$ & $12.82^{\mathrm{b}}$ & $11.78^{\mathrm{b}}$ & $12.49^{\mathrm{b}}$ & 7.520 & $* * *$ \\
\hline
\end{tabular}

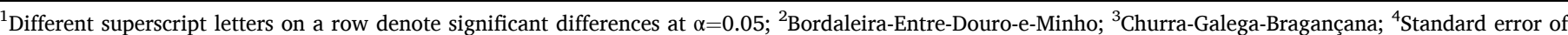
means; ${ }^{5}$ Level of significance $* * * \mathrm{p}<.0001, * * \mathrm{p}<0.01$.

$(1.821 \%)$ and INRA401 (2.350\%). Higher percentage of C14:0 was measured in the extensive and semi- extensive breeds, with maximum levels in Castellana reared in semi-extensive system (5.459\%).

The percentage of MUFA in lamb meat were similar to SFA (34.070 $\%-48.806 \%$ ). The main MUFA constituent is oleic acid (C18:1 n-9cis), displaying lowest levels in the meat of BEDM animals (29.063 \%) in comparison to Gallega (34.615 \%), Castellana (33.869-38.377 \%), CGB $(36.994 \%)$ and INRA401 lambs (37.850 \%). Furthermore, cis-vaccenic acid (C18:1n-7cis) and palmitoleic (C16:1n-7) acid showed also lower percentage in meat from BEDM $(0.624 \%$ and $1.229 \%$, respectively) compared to the rest of the studied breeds $(0.804-1.958 \%$ and $1.488-2.002 \%$, respectively). Significant differences between breeds also existed in regard to the trans isomers elaidic (C18:1n-9trans) and trans-vaccenic (C18:1n-7trans). The lowest percentage of elaidic acid was observed in BEDM $(0.386 \%)$ and semi-extensively reared Castellana $(0.357 \%)$, while the highest was presented in the two intensively 
Table 3

Lipid nutritional indices in lamb meat from different breed $\times$ production systems.

\begin{tabular}{|c|c|c|c|c|c|c|c|c|}
\hline Index $^{1}$ & $\mathrm{BEDM}^{2} / \mathrm{E}$ & Gallega/E & $\mathrm{CGB}^{3} / \mathrm{SE}$ & Castellana/SE & Castellana/ I & INRA401/I & $\mathrm{SEM}^{4}$ & $\mathrm{Sig}^{5}$ \\
\hline$n-6 / n-3$ & $2.28^{c}$ & $1.76^{\mathrm{c}}$ & $7.03^{\mathrm{ab}}$ & $6.09^{\mathrm{bc}}$ & $13.87^{\mathrm{a}}$ & $12.50^{\mathrm{ab}}$ & 7.67 & $* * *$ \\
\hline $\mathrm{P} / \mathrm{S}^{6}$ & $0.56^{\mathrm{a}}$ & $0.31^{\mathrm{b}}$ & $0.38^{\mathrm{b}}$ & $0.28^{\mathrm{b}}$ & $0.30^{\mathrm{b}}$ & $0.31^{\mathrm{b}}$ & 0.25 & $* * *$ \\
\hline $\mathrm{AI}^{7}$ & $0.59^{c}$ & $0.71^{\mathrm{b}}$ & $0.64^{\mathrm{c}}$ & $0.87^{\mathrm{a}}$ & $0.49^{d}$ & $0.55^{\mathrm{cd}}$ & 0.11 & $* * *$ \\
\hline $\mathrm{TI}^{8}$ & $0.83^{c}$ & $1.09^{\mathrm{b}}$ & $1.15^{\mathrm{b}}$ & $1.38^{\mathrm{a}}$ & $1.14^{\mathrm{b}}$ & $1.16^{\mathrm{b}}$ & 0.14 & $* * *$ \\
\hline
\end{tabular}

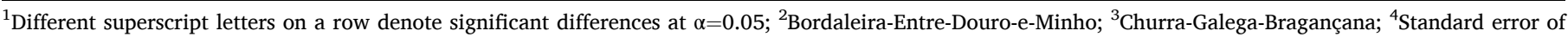
means; ${ }^{5}$ Level of significance ${ }^{* * *} \mathrm{p}<.0001 ;{ }^{6}$ ratio between PUFA and SFA; ${ }^{7}$ Atherogenic index; ${ }^{8}$ Thrombogenic index.

reared breeds (1.279 \% and $1.399 \%$, respectively for Castellana and INRA). In regard to the content of C18:1 n-7 trans, its lowest percentage was observed in the lambs of Castellana breed reared in a semi-extensive system. The patterns described above determined the lowest total percentage of MUFA in BEDM. The highest proportion of MUFA was observed in the two intensively reared breeds - Castellana (48.806 \%) and INRA401 (47.004 \%).

The total amount of PUFA varied within the range of 11.781-23.573 $\%$. The highest proportion was recorded for BEDM (23.573\%) and CGB (15.518\%). Surprisingly, the extensively reared Gallega showed similar PUFA content $(13.757 \%)$ to that of the breeds reared under intensive conditions (11.718-12.493\%). It could be noticed that lamb meat contains significant amounts of C18:2n-6 and C20:4 n-6, which are highest in BEDM meat (9.480 \% and $5.197 \%$, respectively) and lowest in Gallega ( $4.760 \%$ and $2.347 \%$, respectively). Meat from Castellana, CGB and INRA401 breeds presented comparable intermediate levels of C18:2n-6 (6.358-8.474\%) and C20:4n-6 (2.545-3.578\%). When compared to the rest, meat from the extensively raised breeds BEDM and Gallega displayed higher percentage of C18:3n-3 (2.396 \% and 1.596\%, respectively) accompanied with increased levels of the long chain C20:5n-3 (1.734 \% and 1.156 \%, respectively), C22:5n-3 (1.961 \% and $1.111 \%$, respectively) and C22:6n-3 (0.670 \% and $0.340 \%$, respectively). CLA were also indentified in the fraction of PUFA with the highest percentage presented in the meat of Gallega (1.804 \%), followed by BEDM and CGB $(0.824-0.842 \%)$. The lowest CLA content was measured in the intensively raised Castellana (0.197 \%) and INRA 401
(0.185\%).

The lipid nutritional indices presented in Table 3 showed the most favourable values of $n-6 / n-3$ ratio in the lamb meat of Gallega (1.76) and BEDM (2.28). On the other hand, the $\mathrm{P} / \mathrm{S}$ ratio which should exceed 0.4 showed the best values in BEDM meat (0.56), which was significantly higher than the meat from the other breeds. The atherogenic (AI) and thrombogenic (TI) indices take into account the specific roles of the individual fatty acids on the human health. The highest AI was observed in meat from semi-extensively reared Castellana breed (0.87) and Gallega breed (0.71), corresponding to the high percentage of C14:0 and relatively lower content of PUFA determined in these breeds. The meat of INRA401 and Castellana lambs, both reared in intensive system, tended to have lowest $\mathrm{AI}$ ( 0.55 and 0.49 , respectively). The lowest TI was found in meat of BEDM lambs (0.83) and highest one in meat from in semi-extensive Castellana (1.38). Intermediate and comparable mean TI values between 1.09 and 1.16 were quantified in lamb meat from Gallega, CGB, intensive Castellana and INRA401 breeds.

\subsection{Interrelationships among compositional attributes of lamb meat}

Fig. 1 shows the variables factor map obtained from the principal component analysis carried out on selected compositional attributes and lipid nutritional indices of lamb meat. The two first principal components accounted for $74.4 \%$ of the data variability. The first component (44.1 \%) was positively correlated with MUFA $(r=0.866)$, TI $(r=0.859)$ and intramuscular fat content $(r=0.813)$, and inversely

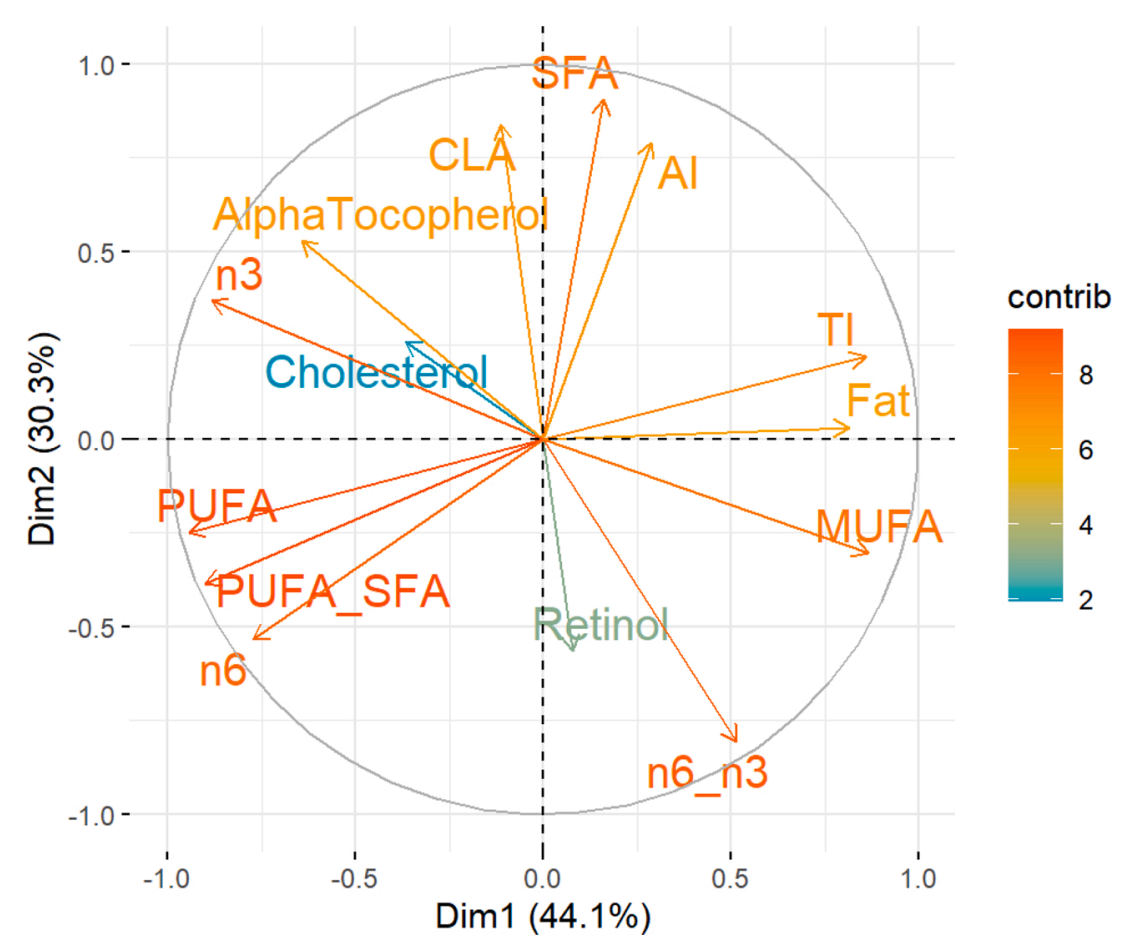

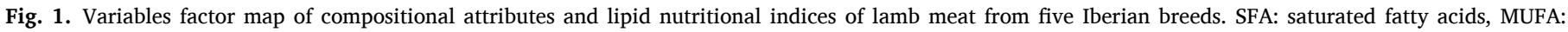
monounsaturated fatty acids, PUFA: polyunsaturated fatty acids, CLA: conjugated linoleic acid, AI: atherogenic index, TI: thrombogenic index. 
correlated with PUFA ( $\mathrm{r}=-0.943)$, PUFA/SFA $(\mathrm{r}=-0.900), \mathrm{n}-3(\mathrm{r}=-0.883)$ and $n-6(r=-0.773)$. The second component $(30.3 \%)$ was positively correlated with SFA $(r=0.906)$, CLA $(r=0.840)$ and AI $(r=0.792)$, and negatively correlated with $n-6 / n-3(r=-0.807)$ and retinol content $(r=-$ 0.564). Apart from those interrelationships, the principal component analysis suggested that lamb meat of lower MUFA tended to have higher contents of alpha-tocopherol and cholesterol.

The projection of the individual loadings onto the bidimensional space evidenced a strong differentiation between breeds and production systems (Fig. 2). In terms of the compositional attributes studied, lamb meat of BEDM and Gallega breeds - both from the Atlantic bioregion were very similar, whereas the quality of meat from intensively raised Castellana and INRA401 greatly overlapped. Similarly, the quality of meat of CGB and semi-extensively raised Castellana breeds were comparable. When grouping individual loadings by production system (Fig. 2, right), the quality of meat from lambs raised in semi-extensive systems was found to lie noticeably between that of the extensive and intensive systems. Meat from extensively raised lambs were associated to higher SFA, CLA, $\alpha$-tocopherol, n-3, AI and cholesterol content, and lower intramuscular fat content, MUFA, n- $6 / n-3$ and retinol content. The opposite is true for the meat from intensively reared lambs.

\section{Discussion}

The chemical composition, fatty acid profile and lipid nutritional indices of the meat could be significantly affected by the breed and the production system of the animals. However, in the context of the present study the combined effect of both factors is discussed since each of the examined breeds is reared under a particular production system to which they are best adapted and respond with the best performance and quality of meat. The latter, in addition, strongly depends on factors such as diet, age and weight of the animals, and these should also be taken into account (Polidori et al., 2017).

Meat is an important source of protein and fat in the human diet. Among all breeds, the low values of these two components, and more substantially the intramuscular fat content, were determined in the meat of extensive BEDM lambs. This, however, was not observed in the meat of Gallega breed, also reared under extensive production system. The latter showed protein and intramuscular fat content which were significantly higher than BEDM and closer to the values reported for the intensively and semi-extensively reared breeds. This difference might be explained by the older slaughter age of the Gallega lambs, and also by the presence of legumes in their diet. The protein content in this study varied between $20.06-21.17 \%$, which does not deviate from the values typically observed in lamb meat (Fowler et al., 2019; Romero-Bernal et al., 2017; Wati et al., 2019). The lower protein content measured in the meat of the extensively reared BEDM lambs is in agreement with Hanekom (2010), who reported less protein in $m$. Longissimus dorsi from extensively reared lambs, but not in $m$. Biceps femoris and $m$. Semimembranosus. This was later confirmed by Popova and Marinova (2013), observing decreased deposition of protein in $m$. Longissimus dorsi in lambs reared on pasture when compared to indoors reared animals from Bulgarian indigenous breeds and crosses. The differences, however, depended on the breed and were not observed in $m$. Semimembranosus.

The intramuscular fat content is an important parameter affecting considerably the sensory traits of meat, especially its tenderness and flavour. Compared to the protein, intramuscular fat content is rather variable. Differences between breeds and effect of production systems on the fat content have been reported but remain inconsistent. In line with our results, Karim et al. (2007) reported lower intramuscular fat content in lambs reared extensively when compared to those reared in semi-extensive and intensive conditions. Aurousseau et al. (2004) and Popova (2007) also showed significantly higher content of intramuscular lipids in intensively reared lambs when compared to the ones reared in extensive system. The decreased lipid deposition in animals reared under extensive system could be attributed to the higher energy expenditures for locomotion and thermoregulation (Vermorel, 1988). On the other hand, later Aurousseau et al. (2007) and Popova and Marinova (2013) did not observe any effect of the rearing system on the intramuscular fat content in lambs.

Cholesterol is present in the muscle as a major component of cell membranes and nerves but also as an active metabolite in the cells. The mean values of cholesterol presented in this study were between 40.97 and $66.88 \mathrm{mg} / 100 \mathrm{~g}$ meat, being lower than reported in other studies (Coutinho et al., 2014; Faria et al., 2012). According to Arsenos, Zygoyjannis, Kufidis, Katsaounis, \& Stamataris (2000), breed is the main factor determining the cholesterol content in the fat of lamb carcasses amidst the nutritional condition and degree of maturity of the animals. Furthermore, Bunch et al. (2004) reported a broad range of cholesterol content in the meat of different breeds of lambs. In our study, cholesterol
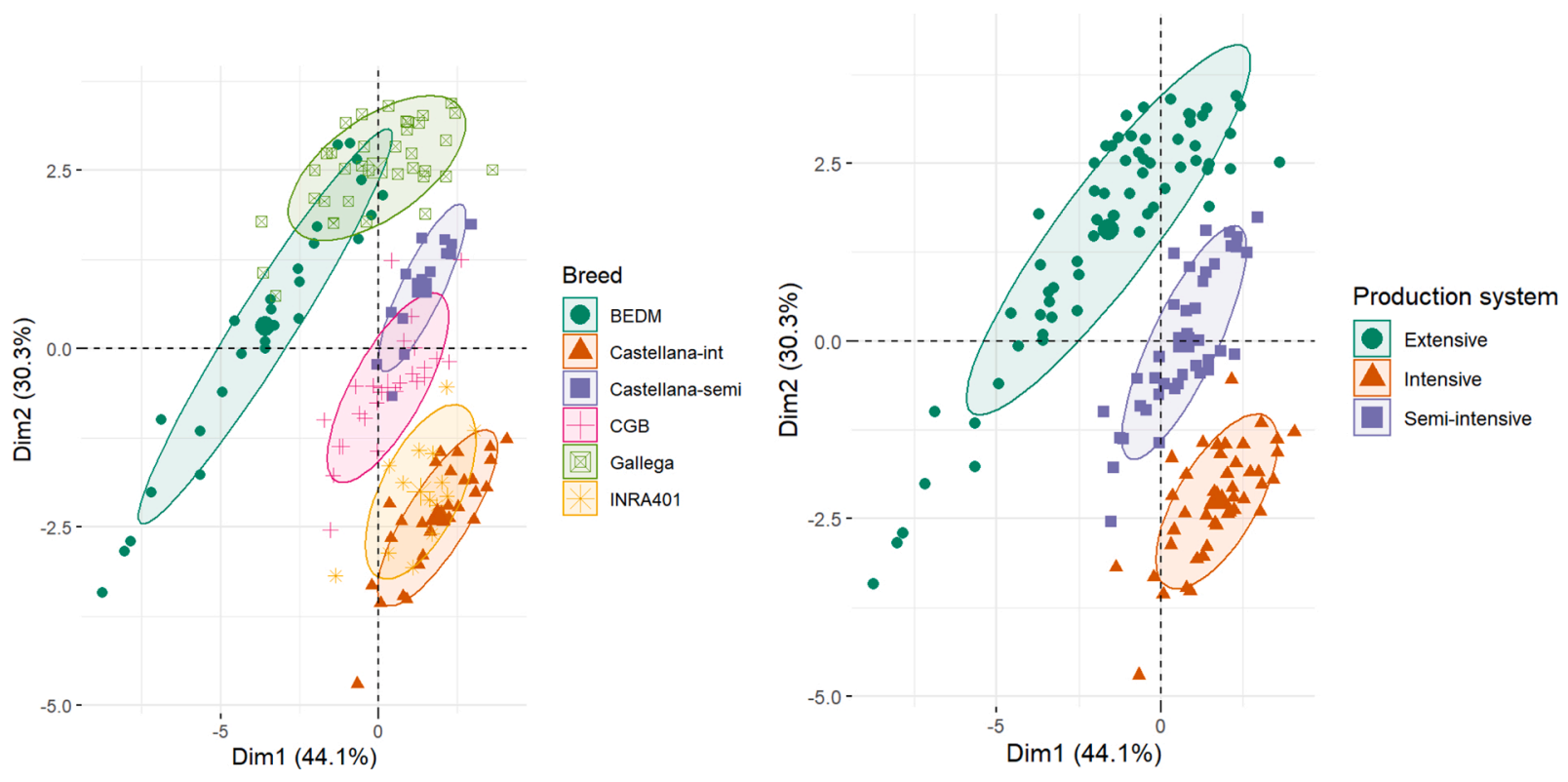

Fig. 2. Individuals factor map of compositional attributes and lipid nutritional indices of lamb meat grouped by breed (left) and by production system (right), with ellipses superimposed at $\alpha=0.95$. 
content depended on the production system as well. The lowest cholesterol content was presented by the intensively reared Castellana lambs, while the highest was observed in Gallega lambs grown under extensive production system. This is in agreement with Arsenos et al. (2000) who observed lower cholesterol content in the fat of lambs reared on pasture than in the animals from the same breeds reared indoors. On the other hand, the lowest cholesterol levels in the meat of intensively reared Castellana lambs was accompanied by the highest intramuscular fat content in these animals. Such negative relationship was observed by Rowe et al. (1999) in lambs fed in drylot, with higher intramuscular fat but lower cholesterol than pastured lambs. Also, Perez et al. (2002) reported decrease in the cholesterol content in lambs with increase of their weight and, hence, the lipid content.

The breeds reared under the specific production systems are clearly differentiated by the content of $\alpha$-tocopherol which shows considerable levels in the meat of BEDM and Gallega lambs, being approximately three to four times higher than the measured in Castellana, CGB and INRA401. This can be attributed to the pasture access and the high content of antioxidants, especially tocopherols, in the plants, which are subsequently accumulated in the animal tissues (Molino et al., 2014; Ponnampalam et al., 2012; Turner et al., 2002). The accumulation of natural antioxidants in the meat from the extensively reared breeds studied in this investigation should be considered as a positive effect of the production system for improved meat quality.

The fatty acid profile of meat is closely related to its dietetic value and is affected mostly by the production systems and feeding strategies applied for the animals. The meat of the ruminants is generally rich in SFA. In the present study, this is particularly noticed in the meat of the extensively reared lambs (BEDM and Gallega), but also in the meat of the lambs from Castellana breed reared in semi-extensive system. The higher proportion of SFA in lambs from the extensive production system was associated with increase in the content of C18:0, which has been reported in other studies (De la Fuente et al., 2009; Karaca et al., 2016). On the other hand, the high amount of SFA in the meat of the semi-extensive Castellana lambs was due to elevated proportions of C14:0 and C16:0. While the latter are hypercholesterolemic and their increased dietary intake is associated with higher risk of development of coronary heart disease, C18:0 has been considered as neutral, which was demonstrated by several studies (Grundy, 1994; Haumann, 1998; Kris-Etherton et al., 2005; Mensink, 2005; Pearson, 1994). The content of C18:0 depends on the biohydrogenation of unsaturated C18 fatty acids and its lower content observed in the lambs from the intensively and semi-extensively reared breeds could be attributed to the diets, based on concentrates. Biohydrogenation requires microbial lipases to hydrolyze ester linkages to free a carboxyl group so that isomerisation and hydrogenation can occur (Sinclair, 2007). The high concentrate diets typical for intensive and semi-extensive systems reduce the rumen $\mathrm{pH}$, leading to inhibition of the lipase activity and hence decreasing the biohydrogenation of the unsaturated fatty acids (Jenkins et al., 2008).

The higher proportion of MUFA and particularly C18:1n-9cis was present in the meat of Castellana, CGB and INRA401 reared in intensive and semi-extensive systems, as well as the Gallega, and corresponded to the high intramuscular fat content in these breeds. According to Lourenço et al. (2007) and Faria et al. (2012), there is a positive relationship between the intramuscular fat content and the oleic acid. It has been demonstrated that the latter has beneficial effect against cancer and inflammatory diseases (Sales-Campos et al., 2013), and its high content in the lamb meat should be considered beneficial for the human health. Her high proportions also compensate for the elevated content of the trans-isomers, particularly elaidic acid (C18:1n-9 trans) that were observed in the animals of the intensively reared breeds. The higher levels of elaidic acid might affect adversely the healthy quality of the meat, since scientific data have revealed the high consumption of this fatty acid to be associated with increased rate of death of cardiovascular disease through acceleration of atherosclerosis (Monguchi et al., 2017). Recently, it was also indicated that elaidic acid enhances cancer progression (Ohmori et al., 2016). Contrary to its action, trans-vaccenic acid has pronounced anticancer activity (Song et al., 2019).

In this study, the meat of all breeds contains considerable amounts of C18:2n- 6 which is the major polyunsaturated fatty acid. Mean contents are elevated in the intensive and semi-extensive breeds; however, surprisingly, a considerable level of C18:2n-6 was observed in the meat of BEDM lambs. C18:2n-6 is an essential fatty acid and exclusively derived from the diet. Its higher contents in the Castellana, INRA104 and CGB compared to Gallega are expected since the diets based on concentrates are rich is C18:2n-6. However, the reported effects of the production system on the content of this fatty acid differ in the literature. In line with our results, Fisher et al. (2000) observed higher contents of C18:2 in meat from concentrate fed Suffolk lambs when compared to the same breed fed grass, but lower in comparison to Soay finished on lowland grass. Furthermore, Cividini et al. (2008) found higher C18:2n-6 contents in meat from pastured lambs than in meat from stable lambs. Contrarily to C18:2n-6, the breeds reared under the particular production systems could be clearly differentiated by the proportion of C18:3 $\mathrm{n}-3$. Both breeds reared in extensive system presented significantly higher content of C18:3n-3 followed by the semi-extensive and intensive breeds, respectively. The higher content of C18:3n-3 in the extensively reared lambs was accompanied by increase in the n-3 PUFA, namely C20:5n-3, C22:5n-3, C22:6n-3. This is in line with the results reported earlier by Díaz et al. (2005); Popova (2007) and Popova (2014). The high content of n-3 PUFA affected favourably the values of $n-6 / n-3$ in BEDM (2.27) and Gallega lambs (1.75). According to Simopoulos (2004), the $n-6 / n-3$ ratio should be below 4.0 in a healthy diet. C18:3n-3 is the most common n-3 fatty acid in food and is a precursor for the synthesis of eicosapentaenoic (C20:5n-3) and docosahexaenoic acid (C22:6n-3) fatty acids (Burdge and Calder, 2005). Their increased dietary intake is recommended due to their biological potency and the numerous benefits for the human health (Siriwardhana et al., 2012). Recently, it was convincingly demonstrated that meat from ruminants, particularly lamb and beef, can be alternative sources of these long chain PUFA, with favourable $n-6 / n-3$ ratio, especially when animals are grazing (Bautista-Martínez et al., 2020; Ferrinho et al., 2020; Hall et al., 2016; Morales et al., 2012; Ponnampalam et al., 2014a, 2014b; Ponnampalam et al., 2014a, 2014b). This is confirmed also by the results presented in this study.

Significant differences between lamb breed $\times$ production systems were observed in regard to the percentage of CLA. The two breeds reared under intensive production systems presented the lowest amounts of CLA, in comparison to the animals grown under extensive and semiextensive conditions. In line with our results, elevated contents of CLA in ruminants reared on pasture have been observed by other authors (Daley et al., 2010; Hall et al., 2016; Leheska et al., 2008; Popova, 2014; Scerra et al., 2011). Conjugated linoleic acid originates from bacterial isomerization or biohydrogenation of PUFA in the rumen and desaturation of trans-fatty acids in the adipose tissue and mammary glands. Microbial biohydrogenation of C18:2n- 6 and C18:3n-3 by the anaerobic rumen bacteria depends strongly on rumen pH (Pariza et al., 2000). Grain consumption decreases rumen $\mathrm{pH}$, hence reducing anaerobic bacteria activity. Conversely, French et al. (2000) suggested that grass diets could favour the growth and activity of bacteria in the rumen, which aids protein breakdown as well as the degradation of fibre and hemicellulose, and stimulates biohydrogenation, subsequently affecting the production of CLA. CLA has drawn much attention due to the claims for their anticancerogenic, antiartherogenic, antidiabetic, and antiadipogenic properties reviewed extensively by Kim et al. (2016) and den Hartigh (2019). The content of CLA in the meat can vary considerably according to the diet but usually is within the range of $0.2 \%-2 \%$ (Khanal and Olson, 2004), which coincides with our results.

The considerable amount of SFA in the lamb meat is associated with the low values of $\mathrm{P} / \mathrm{S}$ ratio. In this study, except for the meat of BEDM, $\mathrm{P} / \mathrm{S}$ ratio is lower than the recommended minimum of 0.4 . On the other hand, the elevated proportion of $\mathrm{C} 14: 0$ is responsible for the higher 
values of AI, particularly in the meat of the extensive and semiextensively raised breeds. AI index determined for the examined breeds presented similar values as those observed by Costa et al. (2009; 2018) and Margetin et al. (2014), and are lower than the mean values determined by Ulbricht and Southgate (1991) for lamb meat (1.00). On the other hand, Costa et al. (2015) determined low AI in lamb meat $(0.27-0.37)$ in three lamb breeds fed different forage: concentrate ratio. This indicates that the dietetic quality of meat can be successfully manipulated through appropriate feeding strategies and rearing systems.

\section{Conclusion}

In conclusion, the combined effect of the breed and production system produces significant differences in the quality characteristics, chemical and fatty acid composition in the lamb meat, with certain advantage for BEDM and Gallega reared under extensive conditions, especially with regards to the elevated amounts of n-3 PUFA and favourable values of $n-6 / n-3$ PUFA, as well as high content of $\alpha$-tocopherol. Furthermore, together with the breeds reared under semiextensive conditions, the lambs grown under extensive system presented higher content of CLA in comparison to the breeds grown in intensive system (Castellana and INRA 401). The latter however showed higher protein content, higher MUFA and lower atherogenic potential than the breeds reared in extensive and semi-extensive conditions. The results of the study show good prospective for further research on these particular breeds and the ways for modification of their feeding strategies in order to obtain meat with high quality and dietetic value.

\section{CRediT authorship contribution statement}

Vasco A.P. Cadavez: Conceptualization, Formal analysis, Funding acquisition, Investigation, Methodology, Project administration, Resources, Software, Visualization, Writing - original draft, Writing - review \& editing. Teodora Popova: Software, Writing - original draft, Writing - review \& editing. Roberto Bermúdez: Investigation, Methodology, Supervision, Validation, Visualization. Koldo Osoro: Funding acquisition, Project administration, Resources, Visualization, Writing review \& editing. Laura Purriños: Investigation, Methodology, Supervision, Validation, Visualization. Raúl Bodas: Funding acquisition, Project administration, Resources, Visualization, Writing - review \& editing. José M. Lorenzo: Conceptualization, Funding acquisition, Investigation, Methodology, Project administration, Resources, Supervision, Visualization, Writing - review \& editing. Ursula GonzalesBarron: Conceptualization, Formal analysis, Funding acquisition, Investigation, Methodology, Project administration, Resources, Software, Visualization, Writing - original draft, Writing - review \& editing.

\section{Declaration of Competing Interest}

The authors report no declarations of interest.

\section{Acknowledgments}

The authors are grateful to EU ERA-NET programme and the Portuguese Foundation for Science and Technology (FCT) for funding the project "EcoLamb-Holistic Production to Reduce the Ecological Footprint of Meat (SusAn/0002/2016). CIMO authors are grateful to FCT and FEDER under Programme PT2020 for financial support to CIMO (UIDB/00690/2020). Dr. Gonzales-Barron acknowledges the national funding by FCT, P.I., through the Institutional Scientific Employment Programme contract. José M. Lorenzo is member of the HealthyMeat network, funded by CYTED (ref. 119RT0568).

\section{References}

Anonymous, 2000. An Evaluation of the Common Organisation of the Markets in the Sheep and Goatmeat Sector. Retrieved July 3, 2020, from The Economic Analyses, Forward Studies and Evaluation Directorate of the European Commission Agriculture Directorate-General website: https://ec.europa.eu/info/food-farming-fis heries/key-policies/common-agricultural-policy/cmef/products-and-markets/ common-organisation-markets-sheep-and-goatmeat-sector_sk.

AOCS, 2005. AOCS official procedure Am5-04. Rapid determination of oil/fat utilizing high temperature solvent extraction. Sampling and Analysis of Vegetable Oil Source Materials AOCS. American Oil Chemists Society., Urbana, IL, USA.

Arsenos, G., Zygoyjannis, D., Kufidis, D., Katsaounis, N., Stamataris, C., 2000. The effect of breed slaughter weight and nutritional management on cholesterol content of lamb carcasses. Small Rumin. Res. 36 (3), 275-283. https://doi.org/10.1016/S09214488(99)00107-8.

Atti, N., Mahouachi, M., 2009. Effects of feeding system and nitrogen source on lamb growth, meat characteristics and fatty acid composition. Meat Sci. 81 (2), 344-348. https://doi.org/10.1016/j.meatsci.2008.08.011.

Aurousseau, B., Bauchart, D., Calichon, E., Micol, D., Priolo, A., 2004. Effect of grass or concentrate feeding systems and rate of growth on triglyceride and phospholipid and their fatty acids in the M. Longissimus thoracis of lambs. Meat Sci. 66 (3), 531-541. https://doi.org/10.1016/S0309-1740(03)00156-6.

Aurousseau, B., Bauchart, D., Faure, X., Galot, A.L., Prache, S., Micol, D., Priolo, A., 2007. Indoor fattening of lambs raised on pasture. Part 1: influence of stall finishing duration on lipid classes and fatty acids in the longissimus thoracis muscle. Meat Sci. 76 (2), 241-252. https://doi.org/10.1016/j.meatsci.2006.11.005.

Barros, J.C., Munekata, P.E.S., de Carvalho, F.A.L., Pateiro, M., Barba, F.J., Domínguez, R., Lorenzo, J.M., 2020. Use of tiger nut (Cyperus esculentus L.) oil emulsion as animal fat replacement in beef burgers. Foods 9 (1), 44. https://doi.org/ 10.3390 /foods 9010044 .

Bautista-Martínez, Y., Hernández-Mendo, O., Crosby-Galván, M.M., Joaquin-Cancino, S., Ruíz Albarrán, M., Salinas-Chavira, J., Granados-Rivera, L.D., 2020. Physicochemical characteristics and fatty acid profile of beef in Northeastern Mexico: grazing vs feedlot systems. Cyta - J. Food 18 (1), 147-152. https://doi.org/ $10.1080 / 19476337.2020 .1725644$.

Bligh, E.G., Dyer, W.J., 1959. A rapid method of total lipid extraction and purification. Can. J. Biochem. Physiol. 37 (8), 911-917. https://doi.org/10.1139/059-099.

Boughalmi, A., Araba, A., 2016. Effect of feeding management from grass to concentrate feed on growth, carcass characteristics, meat quality and fatty acid profile of Timahdite lamb breed. Small Rumin. Res. 144, 158-163. https://doi.org/10.1016/j. smallrumres.2016.09.013.

Bunch, T.D., Evans, R.C., Wang, S., Brennand, C.P., Whittier, D.R., Taylor, B.J., 2004 Feed efficiency, growth rates, carcass evaluation, cholesterol level and sensory evaluation of lambs of various hair and wool sheep and their crosses. Small Rumin. Res. 52 (3), 239-245. https://doi.org/10.1016/j.smallrumres.2003.07.001.

Burdge, G.C., Calder, P.C., 2005. Conversion of $\alpha$-linolenic acid to longer-chain polyunsaturated fatty acids in human adults. Reprod. Nutr. Dev. 45 (5), 581-597. https://doi.org/10.1051/rnd:2005047.

Carrasco, S., Panea, B., Ripoll, G., Sanz, A., Joy, M., 2009. Influence of feeding systems on cortisol levels, fat colour and instrumental meat quality in light lambs. Meat Sci. 83 (1), 50-56. https://doi.org/10.1016/j.meatsci.2009.03.014.

Cividini, A., Levart, A., Žgur, S., 2008. Fatty acid composition of lamb meat as affected by production system, weaning and sex. Acta Agric. Slov. (2), 47-52. Retrieved from. http://aas.bf.uni-lj.si.

Costa, R.G., Batista, A.S.M., Azevedo, P., de, S., Queiroga, R., de, C.R., do, E., Madruga, M.S., Araújo Filho, J.Tde, 2009. Lipid profile of lamb meat from different genotypes submitted to diets with different energy levels. Rev. Bras. Zootec. 38 (3), 532-538. https://doi.org/10.1590/s1516-35982009000300019.

Costa, R.G., Dos Santos, N.M., Do Egypto Queiroga, R., de, C.R., De, Sousa, W.H., Madruga, M.S., Cartaxo, F.Q., 2015. Physicochemical characteristics and fatty acid profile of meat from lambs with different genotypes and diets. Rev. Bras. Zootec. 44 (7), 248-254. https://doi.org/10.1590/S1806-92902015000700003.

Costa, J.B., Oliveira, R.L., Silva, T.M., Barbosa, A.M., Borja, M.S., de Pellegrini, C.B., Bezerra, L.R., 2018. Fatty acid, physicochemical composition and sensory attributes of meat from lambs fed diets containing licuri cake. PLoS One 13 (11), e0206863. https://doi.org/10.1371/journal.pone.0206863.

Coutinho, M.A., Da Graça Morais, M., Coelho, R.G., Alves, F.V., Fernandes, H.J., Ítavo, C. C.B.F., Ribeiro, C.B., 2014. Lipid profile and cholesterol in meat cuts of ewe lambs fed different levels of concentrate. Semina:Ciencias Agrarias 35 (6), 3355-3366. https://doi.org/10.5433/1679-0359.2014v35n6p3355.

Cruz, B.C., Cerqueira, J., Araújo, J.P., Gonzales-Barron, U., Cadavez, V., 2019. Study of Growth Performance of Churra-galega-Bragançana and Bordaleira-de-Entre-Douro-eMinho Lamb Breeds. XVIII Jornadas Sobre Producción Animal, Zaragoza, España, 7 Y 8 De Mayo De 2019. Asociación Interprofesional para el Desarrollo Agrario, pp. 66-68.

Daley, C.A., Abbott, A., Doyle, P.S., Nader, G.A., Larson, S., 2010. December 10). A review of fatty acid profiles and antioxidant content in grass-fed and grain-fed beef. Nutr. J. 9 (1), 10. https://doi.org/10.1186/1475-2891-9-10.

De la Fuente, J., Díaz, M.T., Álvarez, I., Oliver, M.A., Font i Furnols, M., Sañudo, C., Cañeque, V., 2009. Fatty acid and vitamin E composition of intramuscular fat in cattle reared in different production systems. Meat Sci. 82 (3), 331-337. https://doi. org/10.1016/j.meatsci.2009.02.002.

De-Arriba, R., Sánchez-Andrés, A., 2014. Production and Productivity in Eastern and Western European Sheep Farming: a Comparative Analysis. Retrieved July 3, 2020, from Livestock Research for Rural Development website: http://www.lrrd.org/lrr d26/4/arri26066.htm. 
den Hartigh, L.J., 2019. Conjugated linoleic acid effects on Cancer, obesity, and atherosclerosis: a review of pre-clinical and human trials with current perspectives. Nutrients 11 (2), 370. https://doi.org/10.3390/nu11020370.

Díaz, M.T., Álvarez, I., De La Fuente, J., Sañudo, C., Campo, M.M., Oliver, M.A., Cañeque, V., 2005. Fatty acid composition of meat from typical lamb production systems of Spain, United Kingdom, Germany and Uruguay. Meat Sci. 71 (2), 256-263. https://doi.org/10.1016/j.meatsci.2005.03.020.

Domínguez, R., Barba, F.J., Centeno, J.A., Putnik, P., Alpas, H., Lorenzo, J.M., 2018. Simple and rapid method for the simultaneous determination of cholesterol and retinol in meat using normal-phase HPLC technique. Food Anal. Methods 11 (2), 319-326. https://doi.org/10.1007/s12161-017-1001-4.

Ekiz, B., Demirel, G., Yilmaz, A., Ozcan, M., Yalcintan, H., Kocak, O., Altinel, A., 2013. Slaughter characteristics, carcass quality and fatty acid composition of lambs under four different production systems. Small Rumin. Res. 114 (1), 26-34. https://doi. org/10.1016/j.smallrumres.2013.05.011.

Eurostat, 2019. Agriculture, Forestry and Fishery Statistics - 2019 Edition - Product Eurostat. Retrieved July 3, 2020, from European Commission website: https://ec.eur opa.eu/eurostat/web/products-statistical-books/-/KS-FK-19-001.

Faria, P.B., Bressan, M.C., Vieira, J.O., Vicente-Neto, J., Ferrão, S.P.B., Rosa, F.C., Gama, L.T., 2012. Meat quality and lipid profiles in crossbred lambs finished on clover-rich pastures. Meat Sci. 90 (3), 733-738. https://doi.org/10.1016/j. meatsci.2011.11.004.

Ferrinho, A.M., Peripolli, E., Banchero, G., Pereira, A.S.C., Brito, G., La Manna, A., Baldi, F., 2020. Effect of growth path on carcass and meat-quality traits of Hereford steers finished on pasture or in feedlot. Anim. Prod. Sci. 60 (2), 323. https://doi.org/ 10.1071/AN18075.

Fisher, A.V., Enser, M., Richardson, R.I., Wood, J.D., Nute, G.R., Kurt, E., Wilkinson, R. G., 2000. Fatty acid composition and eating quality of lamb types derived from four diverse breed $\times$ production systems. Meat Sci. 55 (2), 141-147. https://doi.org/ 10.1016/S0309-1740(99)00136-9.

Fowler, S.M., Morris, S., Hopkins, D.L., 2019. Nutritional composition of lamb retail cuts from the carcases of extensively finished lambs. Meat Sci. 154, 126-132. https://doi. org/10.1016/j.meatsci.2019.04.016.

French, P., Stanton, C., Lawless, F., O'Riordan, E.G., Monahan, F.J., Caffrey, P.J., Moloney, A.P., 2000. Fatty acid composition, including conjugated linoleic acid, of intramuscular fat from steers offered grazed grass, grass silage, or concentrate-based diets. J. Anim. Sci. 78 (11), 2849. https://doi.org/10.2527/2000.78112849x.

Grundy, S.M., 1994. Influence of stearic acid on cholesterol metabolism relative to other long-chain fatty acids. - Abstract - Europe PMC. Am. J. Clin. Nutr. 60 (Suppl), 986s-990s. Retrieved from. https://europepmc.org/article/med/7977157.

Hall, N., Schönfeldt, H., Pretorius, B., 2016. Fatty acids in beef from grain- and grass-fed cattle: the unique South African scenario. South Afr. J. Clin. Nutr. 29 (2), 55-62. https://doi.org/10.1080/16070658.2016.1216359.

Hanekom, Y., 2010. The Effect of Extensive and Intensive Production Systems on the Meat Quality and Carcass Characteristics of Dohne Merino Lambs. Retrieved from. Stellenbosch : University of Stellenbosch website. https://scholar.sun.ac.za:443/h andle/10019.1/5385.

Haumann, B.F., 1998. Stearic acid: a 'different' saturated fatty acid. Am. Oil Chem. Soc. 9 (3), 202-208.

ISO 1442, 1997. International Standards Meat and Meat Products - Determination of Moisture Content. International Organization for Standarization., Geneva, Switzerland.

ISO 936, 1998. International Standards Meat and Meat Products - Determination of Ash Content. International Organization for Standarization., Geneva, Switzerland.

ISO 937, 1978. International Standardsmeat Andmeat Products - Determination of Nitrogen Content. International Organization for Standarization., Geneva, Switzerland.

Jenkins, T.C., Wallace, R.J., Moate, P.J., Mosley, E.E., 2008. Board-invited review: recent advances in biohydrogenation of unsaturated fatty acids within the rumen microbial ecosystem1. J. Anim. Sci. 86 (2), 397-412. https://doi.org/10.2527/jas.2007-0588.

Karaca, S., Yılmaz, A., Kor, A., Bingöl, M., Cavidoğlu, İ., Ser, G., 2016. The effect of feeding system on slaughter-carcass characteristics, meat quality, and fatty acid composition of lambs. Arch. Anim. Breed. 59 (1), 121-129. https://doi.org/ 10.5194/aab-59-121-2016.

Karim, S.A., Porwal, K., Kumar, S., Singh, V.K., 2007. Carcass traits of Kheri lambs maintained on different system of feeding management. Meat Sci. 76 (3), 395-401. https://doi.org/10.1016/j.meatsci.2006.06.008.

Khanal, R.C., Olson, K.C., 2004. Factors affecting conjugated linoleic acid (CLA) content in milk, meat, and egg: a review. Pak. J. Nutr. 3 (2), 82-98. https://doi.org/ 10.3923/pjn.2004.82.98.

Kim, J.H., Kim, Y., Kim, Y.J., Park, Y., 2016. Conjugated linoleic acid: potential health benefits as a functional food ingredient. Annu. Rev. Food Sci. Technol. 7 (1), 221-244. https://doi.org/10.1146/annurev-food-041715-033028.

Kris-Etherton, P.M., Griel, A.E., Psota, T.L., Gebauer, S.K., Zhang, J., Etherton, T.D., 2005. Dietary stearic acid and risk of cardiovascular disease: intake, sources, digestion, and absorption. Lipids 40 (12), 1193-1200. https://doi.org/10.1007/ s11745-005-1485-y.

Leheska, J.M., Thompson, L.D., Howe, J.C., Hentges, E., Boyce, J., Brooks, J.C., Miller, M.F., 2008. Effects of conventional and grass-feeding systems on the nutrient composition of beef1. J. Anim. Sci. 86 (12), 3575-3585. https://doi.org/10.2527/ jas.2007-0565.

Lourenço, M., Van Ranst, G., De Smet, S., Raes, K., Fievez, V., 2007. Effect of grazing pastures with different botanical composition by lambs on rumen fatty acid metabolism and fatty acid pattern of longissimus muscle and subcutaneous fat. Animal 1 (4), 537-545. https://doi.org/10.1017/S1751731107703531.
Margetin, M., Apolen, D., Oravcova, M., Vavrisinova, K., Peskovicova, m D., Luptakova, L., Blasko, J., 2014. Fatty acids profile of intramuscular fat in light lambs traditionally and artificially reared. J. Cent. Eur. Agric. 15 (1). JCEA. Journal of Central European Agriculture, 15(1), 117-129. Retrieved from https://jcea.agr.hr/ en/issues/article/1421.

Mendelsohn, R., 2003. The challenge of conserving indigenous domesticated animals. Ecol. Econ. 45 (3), 501-510. https://doi.org/10.1016/S0921-8009(03)00100-9.

Mensink, R.P., 2005. Effects of stearic acid on plasma lipid and lipoproteins in humans. Lipids 40 (12), 1201-1205. https://doi.org/10.1007/s11745-005-1486-x.

Molino, F., Blanco, M., González-Calvo, L., Ripoll, G., Calvo, J.H., Joy, M., 2014. Effect of grazing alfalfa on $\alpha$-tocopherol content and FA composition in Longissimus and Semitendinosus muscles of light lambs. Options Méditerranéennes, A 109, 359-362. Retrieved from. https://citarea.cita-aragon.es/citarea/handle/10532/2689.

Monguchi, T., Hara, T., Hasokawa, M., Nakajima, H., Mori, K., Toh, R., Shinohara, M., 2017. Excessive intake of trans fatty acid accelerates atherosclerosis through promoting inflammation and oxidative stress in a mouse model of hyperlipidemia. J. Cardiol. 70 (2), 121-127. https://doi.org/10.1016/j.jjcc.2016.12.012.

Morales, R., Folch, C., Iraira, S., Teuber, N., Realini, C.E., 2012. Nutritional quality of beef produced in Chile from different production systems. Chil. J. Agric. Res. 72 (1), 80-86. https://doi.org/10.4067/S0718-58392012000100013.

Nürnberg, K., Wegner, J., Ender, K., 1998. Factors influencing fat composition in muscle and adipose tissue of farm animals. Livest. Prod. Sci. 56 (2), 145-156. https://doi. org/10.1016/S0301-6226(98)00188-2.

Ohmori, H., Fujii, K., Kadochi, Y., Mori, S., Nishiguchi, Y., Fujiwara, R., Kuniyasu, H., 2016. Elaidic acid, a trans-fatty acid, enhances the metastasis of colorectal cancer cells. Pathobiology 84 (3), 144-151. https://doi.org/10.1159/000449205.

Pariza, M.W., Park, Y., M.E, Cook, 2000. Mechanisms of action of conjugated linoleicacid: evidence and speculation. Proc. Soc. Exp. Biol. Med. 32, 853-858.

Pearson, T.A., 1994. Stearic acid: a unique saturated fatty acid. Am. J. Clin. Nutr. 60 (Suppl), 983s-1072s.

Perez, O.J.R., Bressan, M.C., Bragagnolo, N., Prado, O.V., Lemos, A.L., da, S.C., Bonagurio, S., 2002. Effects of different lamb breeds and their slaughter weights on cholersterol, fatty acids and proximate composition. Food Sci. Technol. 22 (1), 11-18. https://doi.org/10.1590/s0101-20612002000100003.

Polidori, P., Pucciarelli, S., Cammertoni, N., Polzonetti, V., Vincenzetti, S., 2017. The effects of slaughter age on carcass and meat quality of Fabrianese lambs. Small Rumin. Res. 155, 12-15. https://doi.org/10.1016/j.smallrumres.2017.08.012.

Ponnampalam, E.N., Burnett, V.F., Norng, S., Warner, R.D., Jacobs, J.L., 2012. Vitamin E and fatty acid content of lamb meat from perennial pasture or annual pasture systems with supplements. Anim. Prod. Sci. 52 (4), 255. https://doi.org/10.1071/ AN11054.

Ponnampalam, Eric N., Butler, K.L., Jacob, R.H., Pethick, D.W., Ball, A.J., Hocking Edwards, J.E., Hopkins, D.L., 2014a. Health beneficial long chain omega-3 fatty acid levels in Australian lamb managed under extensive finishing systems. Meat Sci. 96 (2), 1104-1110. https://doi.org/10.1016/j.meatsci.2013.04.007.

Ponnampalam, Eric N., Butler, K.L., Pearce, K.M., Mortimer, S.I., Pethick, D.W., Ball, A. J., Hopkins, D.L., 2014b. Sources of variation of health claimable long chain omega3 fatty acids in meat from Australian lamb slaughtered at similar weights. Meat Sci. 96 (2), 1095-1103. https://doi.org/10.1016/j.meatsci.2012.11.039.

Popova, T., 2007. Effect of the rearing system on the fatty acid composition and oxidative stability of the M. Longissimus lumborum and M. Semimembranosus in lambs. Small Rumin. Res. 71 (1-3), 150-157. https://doi.org/10.1016/j. smallrumres.2006.06.001.

Popova, T., 2014. Fatty acid composition of longissimus dorsi and semimembranosus muscles during storage in lambs reared indoors and on pasture. Emir. J. Food Agric. 26 (3), 302-308. https://doi.org/10.9755/ejfa.v26i3.16771.

Popova, T., Marinova, P., 2013. Carcass composition and meat quality in lambs reared indoors and on pasture. J. Agric. Sci. Technol. 5 (3), 325-330. Retrieved from. https ://www.researchgate.net/publication/260121612_Carcass_composition_and_meat_ quality_in_lambs_reared_indoors_and_on_pasture.

Romero-Bernal, J., Almaraz, E.M., Ortega, O.A.C., Salas, N.P., González-Ronquillo, M., 2017. Chemical composition and fatty acid profile in meat from grazing lamb diets supplemented with ryegrass hay, fishmeal and soya bean meal as PUFA sources. Cienc. Rural 47 (4), e20160533. https://doi.org/10.1590/0103-8478cr20160533.

Roselló-Soto, E., Barba, F.J., Lorenzo, J.M., Dominguez, R., Pateiro, M., Mañes, J., Moltó, J.C., 2019. Evaluating the impact of supercritical-CO 2 pressure on the recovery and quality of oil from "horchata" by-products: fatty acid profile, $\alpha$-tocopherol, phenolic compounds, and lipid oxidation parameters. Food Res. Int. 120, 888-894. https://doi.org/10.1016/j.foodres.2018.11.054.

Rowe, A., MacEdo, F.A.F., Visentainer, J.V., Souza, N.E., Matsushita, M., 1999. Muscle composition and fatty acid profile in lambs fattened in drylot or pasture. Meat Sci. 51 (4), 283-288. https://doi.org/10.1016/S0309-1740(98)00063-1.

Sales-Campos, H., Reis de Souza, P., Crema Peghini, B., Santana da Silva, J., Ribeiro Cardoso, C., 2013. An overview of the modulatory effects of oleic acid in health and disease. Mini Rev. Med. Chem. 13 (2), 201-210. https://doi.org/10.2174/ 138955713804805193.

Scerra, M., Luciano, G., Caparra, P., Foti, F., Cilione, C., Giorgi, A., Scerra, V., 2011. Influence of stall finishing duration of Italian Merino lambs raised on pasture on intramuscular fatty acid composition. Meat Sci. 89 (2), 238-242. https://doi.org/ 10.1016/j.meatsci.2011.04.012.

Simopoulos, A.P., 2004. Omega-6/omega-3 essential fatty acid ratio and chronic diseases. Food Rev. Int. 20 (1), 77-90. https://doi.org/10.1081/FRI-120028831.

Sinclair, L.A., 2007. Nutritional manipulation of the fatty acid composition of sheep meat: a review. J. Agric. Sci. 145 (5), 419-434. https://doi.org/10.1017/ S0021859607007186. 
Siriwardhana, N., Kalupahana, N.S., Moustaid-Moussa, N., 2012. Health benefits of n-3 polyunsaturated fatty acids. Eicosapentaenoic acid and docosahexaenoic acid. In: Advances in Food and Nutrition Research, vol. 65, pp. 211-222. https://doi.org/ 10.1016/B978-0-12-416003-3.00013-5.

Song, J., Wang, Y., Fan, X., Wu, H., Han, J., Yang, M., Nie, G., 2019. Trans-vaccenic acid inhibits proliferation and induces apoptosis of human nasopharyngeal carcinoma cells via a mitochondrial-mediated apoptosis pathway. Lipids Health Dis. 18 (1) https://doi.org/10.1186/s12944-019-0993-8.

Turner, K.E., McClure, K.E., Weiss, W.P., Borton, R.J., Foster, J.G., 2002. Alphatocopherol concentrations and case life of lamb muscle as influenced by concentrate or pasture finishing - PubMed. J. Anim. Sci. 80 (10), 2513-2521. Retrieved from. htt ps://pubmed.ncbi.nlm.nih.gov/12413072/.

Ulbricht, T.L.V., Southgate, D.A.T., 1991. Coronary heart disease: seven dietary factors. Lancet 338 (8773), 985-992. https://doi.org/10.1016/0140-6736(91)91846-M.

Vermorel, M., 1988, nutrition energetique (energy nutrition). In: Jarrige, R. (Ed.), Alimentation Des Bovins, Ovins and Caprins. INRA, Paris, France, pp. 57-74.

Wati, A.K., Widyawati, S.D., Suprayogi, W.P.S., Riyanto, J., 2019. The meat chemical quality of lamb's longissimus dorsi muscles with addition of saponified animal and vegetable oil in the ration - IOPscience. IOP Conf. Series: Earth Environ. Sci. 250, 012077. Retrieved from. https://iopscience.iop.org/article/10.1088/1755-1315 /250/1/012077. 